Jurnal Ekonomi, Bisnis, dan Akuntansi (JEBA) Volume 21 Nomor 02 Tahun 2019

\title{
PENGARUH KOMPETENSI GURU, KEPEMIMPINAN KEPALA SEKOLAH MENURUT PERSEPSI GURU DAN MOTIVASI KERJA TERHADAP KINERJA GURU SMK NEGERI DI KABUPATEN PURBALINGGA
}

\author{
Heru Mei Giantoro')Haryadi, Ratno Purnomo') \\ Program Pascasarjana Magister Manajemen Universitas Jendral Soedirman Purwokerto ${ }^{1)}$ \\ Fakultas Ekonomi dan Bisnis Magister Manajemen Universitas Jendral Soedirman Purwokerto2) \\ herugiantoro@yahoo.co.id
}

\begin{abstract}
The background of this research is that the success determinant of education in Indonesia is one of the teachers' performance at school. This research was conducted in State Vocational School Purbalingga Regency with the aim of analyzing influence of teacher competence, principals' leadership and work motivation to the teacher performance of State Vocational School in Purbalingga Regency either simultaneously or partially. Data were collected by questionnaire method on 187 teachers of State Vocational School in Purbalingga Regency by using proportional random sampling technique. The results of this research are (1) teacher competence has a positive and significant effect to the teacher performance, (2) principal leadership doesn't have a positive significant effect on teacher performance, and (3) work motivation has a positive and significant effect on teacher performance.
\end{abstract}

Keywords : Teacher competence, principals' leadership, work motivation, teacher performance

\section{ABSTRAK}

Penelitian ini dilatar belakangi bahwa penentu keberhasilan pendidikan di Indonesia salah satunya yakni melalui kinerja guru di sekolah. Penelitian ini dilakukan di SMK Negeri se Kabupaten Purbalingga dengan tujuan menganalisis pengaruh kompetensi guru, kepemimpinan kepala sekolah dan motivasi kerja terhadap kinerja guru SMK Negeri di Kabupaten Purbalingga baik secara simultan maupun parsial. Data dikumpulkan dengan metode kuesioner terhadap 187 guru SMK Negeri di Kabupaten Purbalingga dengan menggunakan metode proportional random sampling. Hasil dari penelitian ini adalah (1) kompetensi guru berpengaruh positif dan signifikan terhadap kinerja guru, (2) kepemimpinan kepala sekolah tidak berpengaruh signifikan yang positif terhadap kinerja guru, dan (3) motivasi kerja berpengaruh positif dan signifikan terhadap kinerja guru.

Kata kunci : kompetensi guru, kepemimpinan kepala sekolah, motivasi kerja, kinerja guru.

\section{PENDAHULUAN}

Guru merupakan salah satu penentu keberhasilan pendidikan di Indonesia melalui kinerjanya di sekolah. Seorang guru dituntut senantiasa untuk terus mengasah dan meningkatkan kompetensinya mengikuti perkembangan ilmu pengetahuan dan teknologi terbaru guna mendukung kinerjanya sebagai pendidik dan pengajar. Setiap satuan pendidikan memiliki kurikulum tingkat satuan pendidikan (KTSP). Guru yang berkualitas akan mampu mendukung KTSP yang kurang baik dengan inovasinya. Hal ini seperti yang ditegaskan oleh Mulyasa bahwa betapapun bagusnya kurikulum yang diterapkan suatu sekolah, tetap hasilnya sangat ditentukan pada pencapaian yang diperoleh oleh guru dan juga siswa di dalam pembelajaran 
(Mulyasa, 2005: 147). Artinya keberhasilan suatu kurikulum di tingkat satuan pendidikan sangat tergantung pada kinerja guru. Penilaian kinerja guru SMK Negeri se kabupaten Purbalingga dapat dilihat pada tabel 1

Tabel 1. Skor Penilaian Kinerja Guru (PKG) SMK Negeri se Kabupaten Purbalingga Tahun Pelajaran 2017/2018

\begin{tabular}{|c|c|c|c|c|c|c|}
\hline \multirow{2}{*}{ No } & \multirow{2}{*}{$\begin{array}{l}\text { Skor } \\
\text { PKG }\end{array}$} & \multicolumn{4}{|c|}{ Jumlah Guru Dilihat Dari Usia } & \multirow{2}{*}{ Jumlah } \\
\hline & & $<30$ & $31-40$ & $41-50$ & $51-60$ & \\
\hline 1 & 46 & 2 & & & & 2 \\
\hline 2 & 47 & 2 & 4 & 3 & & 9 \\
\hline 3 & 48 & 2 & 36 & 8 & 2 & 48 \\
\hline 4 & 49 & & 9 & & 2 & 11 \\
\hline 5 & 50 & & 12 & 28 & 10 & 50 \\
\hline \multicolumn{2}{|c|}{ Total } & 6 & 61 & 39 & 14 & 120 \\
\hline
\end{tabular}

Sumber: Skor PKG Guru SMK Negeri di Purbalingga Sebanyak 120 Guru

Dari tabel 1 diperoleh data dari 120 guru SMK Negeri di Kabupaten Purbalingga, didapat hasil penilaian kinerja guru yakni yang mendapatkan skor 46 sebanyak 2 guru (1,67\%), skor 47 sebanyak 9 guru (7,50\%), skor 48 sebanyak 48 guru (40\%), skor 49 sebanyak 11 guru $(9,17 \%)$, dan skor 50 sebanyak 50 guru $(41,66 \%)$. Berdasarkan sebutan untuk penilaian kinerja guru dapat dikatakan semua guru SMK Negeri di Kabupaten Purbalingga memiliki kinerja yang baik. Dari data diatas didapatkan juga bahwa guru yang mendapatkan nilai 50 sebagian besar berada pada usia 41-50 tahun yakni sebanyak 28 guru (23,33\%), sedangkan untuk perolehan nilai yang paling banyak yakni nilai 48 pada usia guru 31-40 tahun sebanyak 36 guru (30\%). Namun sampai sejauh ini ada hal yang menarik dengan kondisi tersebut, yakni belum diketahui variabel apa saja yang dapat mempengaruhi peningkatan kinerja guru SMK Negeri se Kabupaten Purbalingga.

Kompetensi seorang guru mempengaruhi kinerjanya pada saat melaksanakan proses belajar mengajar, dimana kompetensi seorang guru terdiri dari kompetensi pedagogik, kompetensi kepribadian, kompetensi sosial dan kompetensi profesional. Selain itu dilihat dari faktor motivasi guru yang dipengaruhi oleh tunjangan sertifikasi, status kepegawaian, penghasilan, linearitas tugas terhadap ijazah juga kemungkinan dapat mempengaruhi kinerja guru. Kepemimpinan seorang Kepala Sekolah pun bisa mempengaruhi kinerja guru. Untuk itu peningkatan kinerja guru perlu terus diupayakan dengan memperhatikan faktor-faktor yang dapat mempengaruhi kinerja guru

Penelitian terdahulu yang dilakukan oleh Setyono (2011) menunjukkan bahwa terdapat pengaruh positif kompetensi guru terhadap kinerja guru, dimana apabila kompetensi yang dimiliki oleh seorang guru baik, akan dapat membuat kinerja guru menjadi lebih baik. Hasil penelitian Pratiwi (2013) menyatakan terdapat pengaruh positif dari kepemimpinan kepala sekolah menurut persepsi guru terhadap kinerja guru, dimana apabila kepemimpinan seorang kepala sekolah baik menurut persepsi guru maka akan dapat membuat kinerja guru menjadi baik. Selanjutnya dalam penelitian Setiyati (2014) menyatakan ada pengaruh yang positif dan signifikan antara motivasi kerja terhadap kinerja guru, apabila motivasi kerja seorang guru tinggi maka akan dapat membuat kinerja guru menjadi baik.

Berdasarkan latar belakang yang telah diuraikan di atas, maka penulis bermaksud mengadakan penelitian "Pengaruh Kompetensi Guru, Kepemimpinan Kepala Sekolah Menurut Persepsi Guru, dan Motivasi Kerja terhadap Kinerja Guru SMK Negeri di 
Kabupaten Purbalingga". Dengan penelitian ini, diharapkan akan didapatkan informasi dalam menjawab permasalahan-permasalahan yang terjadi pada kinerja guru, sehingga nantinya akan dapat membuat kinerja guru SMK Negeri di Kabupaten Purbalingga menjadi lebih baik.

\section{TINJAUAN PUSTAKA \\ Kinerja Guru}

Depdiknas (2004: 11) menyatakan kinerja guru adalah kemampuan yang dimiliki guru guna menunjukkan berbagai kemampuan dan kompetensinya. Kinerja guru menurut Supardi (2014: 54) adalah usaha yang dilakukan oleh seorang guru didalam kegiatan belajar mengajar guna meningkatkan hasil belajar anak didiknya. Dengan demikian, kinerja guru dapat menunjukkan kemampuan seorang guru dalam melaksanakan aktivitas pembelajaran serta menggambarkan adanya suatu perbuatan yang dilakukan guru dan menghasilkan tujuan yang diinginkan. Kinerja guru adalah hasil kerja guru yang digambarkan dari kompetensi yang dimilikinya ketika menghadapi situasi dan kondisi pekerjaannya di sekolah, yang terbentuk oleh sikap dan perilakunya (Rizal, 2015).

Menurut Siregar (2011) tujuan dari kinerja individual guru yaitu: (a) meningkatkan prestasi kerja guru, baik secara individu maupun dalam kelompok, dimana peningkatan prestasi kerja guru berdampak pada peningkatan kinerja guru; (b) menumbuhkan minat dalam pengembangan keprofesiannya dengan meningkatkan hasil kerja melalui prestasi kerja, dan (c) memberikan kesempatan kepada guru untuk menyampaikan perasaannya mengenai pekerjaannya di sekolah, sehingga akan terjadi komunikasi dua arah yang baik antara kepala sekolah selaku pimpinan dan guru selaku bawahannya.

Menurut Timpe (1993: 32) beberapa faktor yang mempengaruhi kinerja guru adalah : (1) lingkungan kerja, (2) motivasi kerja, (3) gaya kepemimpinan kepala sekolah, (4) perilaku, (5) sikap, dan (6) hubungan dengan sesama guru. Syadam (1996: 486) menyatakan faktorfaktor yang mempengaruhi kinerja seorang guru dalam melaksanakan pekerjaannya yaitu: (1) tingkat kependidikan, (2) pengalaman kerja, (3) lingkungan kerja, (4) peralatan atau sarana pendukung, (5) kepemimpinan, dan (6) motivasi kerja guru itu sendiri. Wibowo (2007: 87) mengatakan bahwa kinerja guru dipengaruhi oleh pengetahuan, kemampuan, sikap, gaya kerja, kepribadian, minat, dasar-dasar nilai, kepercayaan dan gaya kepemimpinan kepala sekolah.

\section{Kompetensi Guru}

Menurut Anderson S \& Ball S (1978: 3), kompetensi guru adalah seperangkat pengetahuan, kemampuan dan keterampilan yang dimiliki seorang guru dan ditampilkan dalam kegiatan belajar mengajar. Menurut Sahertian (1994: 73), menyatakan bahwa kompetensi guru adalah seperangkat kemampuan yang harus dimiliki guru sesuai dengan tuntutan kebutuhan pendidikan di sekolah, masyarakat, dunia usaha/industri dan perkembangan ilmu pengetahuan dan teknologi. Kompetensi guru menurut (Dill, 1999) adalah pengetahuan yang dimiliki oleh guru dalam hal pengajaran (pedagogik) pada bidang yang ia ajarkan (profesional), dan hal-hal yang berkaitan dengan kehidupan sosial di masyarakat (sosial) serta sifat pribadinya terhadap orang lain (kepribadian). Suparlan (2006: 81) kompetensi guru adalah pengetahuan, sikap, keterampilan dan nilai-nilai yang ditunjukkan guru dalam melaksanakan kinerja yang diberikan kepadanya. Menurut Kunandar (2007: 55) kompetensi guru adalah seperangkat penguasaan kemampuan yang harus ada dalam diri guru agar dapat mewujudkan kinerjanya secara tepat dan efektif. Mulyasa (2007: 75) menyatakan kompetensi yang harus dimiliki guru yakni 
kompetensi pedagogik, kompetensi kepribadian, kompetensi profesional, dan kompetensi sosial.

Menurut (Kunandar, 2007: 77) manfaat dari kompetensi guru adalah : (1) sebagai alat untuk mengembangkan dan meningkatkan standar kemampuan profesional guru, (2) sebagai alat seleksi penerimaan guru baru, (3) untuk pengelompokan guru mata pelajaran, (4) sebagai bahan acuan dalam pengembangan kurikulum tingkat satuan pendidikan, (5) merupakan alat pembinaan guru, dan (6) mendorong kegiatan pembelajaran dan hasil belajar yang lebih baik.

\section{Kepemimpinan Kepala Sekolah Menurut Persepsi Guru}

Purwanto (1990: 26) kepemimpinan adalah kemampuan dari pribadi seseorang untuk meyakinkan anggotanya agar mereka mau dan dapat melaksanakan tugas yang diberikan kepadanya dengan rela, penuh semangat, ada kegembiraan batin, serta merasa tidak terpaksa. Kepemimpinan adalah suatu proses menggerakkan seluruh anggota dalam suatu organisasi karena memiliki kekuasaan, kewibawaan dan kemampuan, agar bekerja dalam suasana moralitas yang tinggi dan penuh semangat untuk dapat menyelesaikan pekerjaannya masingmasing guna mencapai hasil yang diharapkan organisasi (Salam, 2002). Kepemimpinan menurut Wahyudi (2009: 120) adalah kemampuan seseorang dalam menggerakkan, mengarahkan, sekaligus mempengaruhi pola pikir, cara kerja setiap anggota dalam bekerja agar tujuan cepat tercapai.

Menurut Rahman dkk (2006: 106) kepala sekolah adalah seseorang guru yang diberi tugas tambahan untuk memimpin dan mengelola suatu sekolah. Sedangkan menurut Wahjosumidjo (2011: 83) mengemukakan bahwa kepala sekolah adalah seorang guru yang diberi tugas tambahan untuk memimpin suatu sekolah guna mengelola terlaksananya proses belajar mengajar yang baik antara guru dengan peserta didik. Menurut Poerwadarminta (1990: 759) persepsi adalah respon langsung dari suatu kejadian atau proses seseorang mengetahui beberapa hal melalui penginderaan. Persepsi menurut Wagner dan Hollenbeck (1995) adalah sebuah proses dimana seseorang dapat memilih, mengelola, menyimpan, serta menggambarkan informasi-informasi yang diterima melalui kelima panca indera. Slameto (2010: 102) persepsi adalah proses pentransferan informasi kedalam otak manusia yang terjadi secara terus menerus berhubungan dengan lingkungan sekitarnya. Dari berbagai pengertian di atas maka dapat diambil kesimpulan bahwa kepemimpinan kepala sekolah berdasarkan persepsi guru adalah kemampuan seorang kepala sekolah untuk menggerakkan sumber yang ada pada suatu sekolah dan digunakan secara maksimal untuk mencapai tujuan sekolah yang telah ditetapkan.

Murni (2010: 25) menyatakan fungsi kepemimpinan kepala sekolah adalah : (1) memberikan kesadaran dan penuh semangat agar seluruh warga sekolah melaksanakan tugas masing-masing dalam mencapai tujuan sekolah; (2) bertanggung jawab menyediakan segala dukungan, peralatan, fasilitas dan suasana yang mendukung agar guru, staf dan siswa melaksanakan tugas dengan penuh kesadaran; (3) mampu memahami motivasi setiap guru, staf dan siswa, bersikap dan berperilaku baik yang bersifat positif maupun reaksi yang tidak mendukung; (4) tampak sebagai sosok yang dihargai, terpercaya, dituruti segala perintahnya, sehingga betul-betul berfungsi sebagai sumber inspirasi bawahan; (5) dapat menjaga keseimbangan guru, staf dan siswa di satu pihak dan kepentingan sekolah serta kepentingan masyarakat di lain pihak sehingga tercipta suasana keseimbangan, keserasian antar kehidupan sekolah dengan masyarakat; (6) menyadari esensi kepemimpinan adalah pengikut, artinya kepemimpinan tidak akan terjadi apabila tidak didukung pengikut atau bawahan; (7) memberikan bimbingan, mengadakan koordinasi kegiatan, mengadakan pengendalian atau 
pengawasan dan mengadakan pembinaan agar masing-masing anggota atau bawahan memperoleh tugas yang wajar dalam beban dan hasil usaha bersama.

\section{Motivasi Kerja}

Winardi (2002: 6) menyatakan motivasi kerja adalah suatu kekuatan yang ada dalam diri seseorang dan dipengaruhi oleh faktor luar berdampak pada hasil kinerjanya berdasarkan situasi dan kondisi yang dihadapi orang tersebut. Berelson dan Steiner dalam (Sastrohadiwiryo, 2002) motivasi kerja adalah kondisi kejiwaan dan mental seseorang yang memberikan energi untuk melakukan pekerjaan guna terpenuhinya kebutuhan dan merasakan kepuasan. Uno (2008: 73) motivasi kerja adalah kekuatan yang muncul dari seseorang karena suatu pengaruh yang mendorongnya bersikap agar tujuannya tercapai. Sedangkan menurut (Newstrom, 2011: 109) motivasi kerja adalah hasil dari kumpulan kekuatan internal dan eksternal yang menyebabkan seseorang memilih pekerjaan yang diinginkan dan berperilaku kerja tertentu untuk mencapai tujuan organisasi.

Menurut Hasibuan (2007: 97) pemberian motivasi mempunyai beberapa tujuan yang antara lain adalah: (1) mendorong gairah dan semangat kerja karyawan; (2) meningkatkan produktivitas kerja karyawan; (3) meningkatkan moral dan kepuasan kerja karyawan; (4) meningkatkan kedisiplinan dan menurunkan tingkat absensi karyawan; (5) mempertahankan loyalitas dan kestabilan karyawan; (6) menciptakan suasana dan hubungan kerja yang baik; (7) meningkatkan tingkat kesejahteraan karyawan; (8) meningkatkan kreativitas dan partisipasi karyawan; (9) mengefektifkan perekrutan karyawan; (10) mempertinggi rasa tanggung jawab karyawan terhadap tugas-tugasnya.

\section{Model Penelitian}

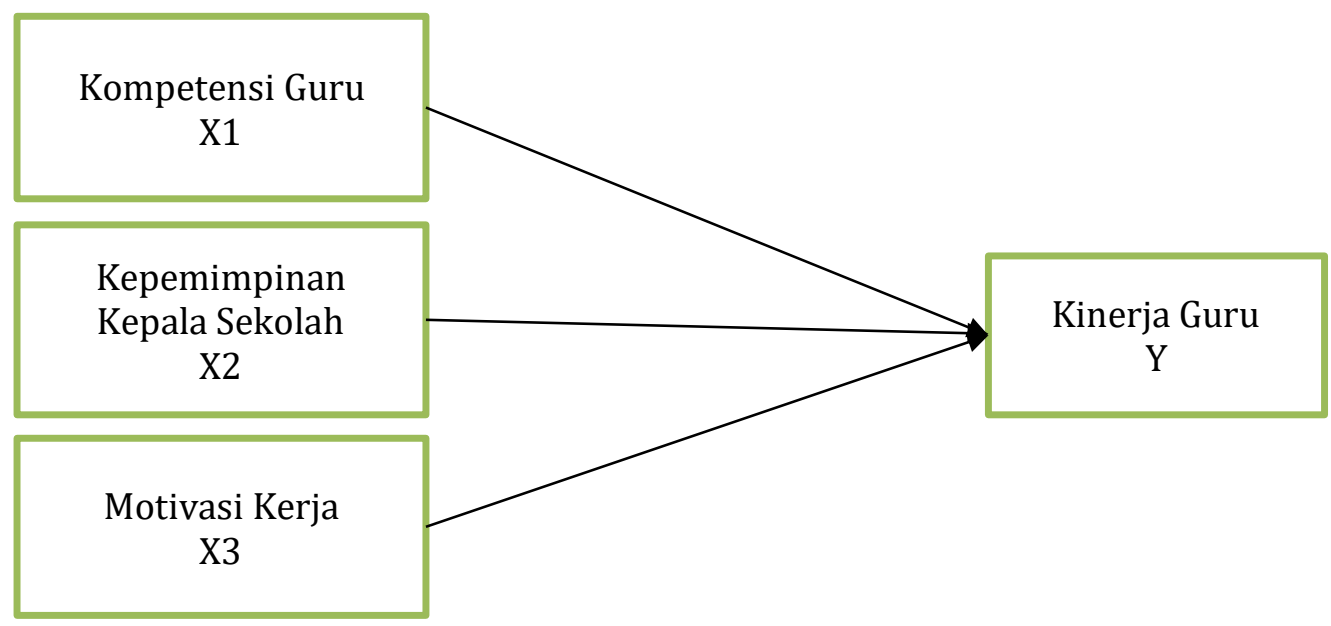

Gambar 1 Model Penelitian

\section{Hipotesis}

Hipotesis dalam penelitian ini berdasarkan rumusan masalah, tinjauan pustaka dan penelitian terdahulu adalah :

H1 : Kompetensi guru berpengaruh positif dan signifikan terhadap kinerja guru SMK Negeri di Kabupaten Purbalingga.

H2 : Kepemimpinan Kepala Sekolah berpengaruh positif dan signifikan terhadap kinerja guru SMK Negeri di Kabupaten Purbalingga. 
H3 : Motivasi kerja berpengaruh positif dan signifikan terhadap kinerja guru SMK Negeri di Kabupaten Purbalingga.

\section{METODE PENELITIAN}

Penelitian ini menggunakan penelitian kuantitatif dengan menggunakan pendekatan survey, yaitu menggunakan perangkat kuesioner tertulis untuk mendapatkan informasi. Penelitian ini merupakan penelitian expost facto yakni penelitian dari suatu kejadian yang sebelumnya terjadi dan kemudian ditinjau kembali untuk mengetahui faktor-faktor yang dapat menyebabkan kejadian tersebut (Sugiyono, 2015: 7). Jenis data dalam penelitian ini adalah data kuantitatif. Data kuantitatif yang digunakan peneliti dalam penelitian ini adalah data yang diperoleh dari kuesioner yang telah diisi sesuai dengan pernyataan responden. Sumber data dalam penelitian ini adalah data Primer yang diperoleh langsung berupa hasil jawaban tertulis terhadap kuesioner. Sedangkan data sekunder dalam penelitian ini adalah data yang diperoleh dari media elektronik internet, data nilai UKG tahun 2015, dan data nilai kinerja guru pada masing-masing sekolah yang memiliki hubungan dengan penelitian ini. Populasi dalam penelitian adalah guru SMK Negeri di Kabupaten Purbalingga yang mengajar sebelum tahun 2015. Metode pengambilan sampel dalam penelitian ini adalah cluster random sampling dengan teknik pengambilan sampelnya adalah dengan menggunakan teknik proportional random sampling. Dengan menggunakan rumus Slovin didapatkan sampel penelitian sejumlah 187 guru. Metode analisis data yang digunakan dalam penelitian ini adalah analisis regresi linier berganda.

\section{HASIL DAN PEMBAHASAN}

\section{Analisis Korelasi}

Hasil analisis korelasi untuk variabel kompetensi guru (X1), kepemimpinan kepala sekolah (X2), motivasi kerja (M) dan kinerja guru (Y) ditunjukkan oleh tabel 2

Tabel 2. Rangkuman Hasil Analisis Korelasi

\begin{tabular}{lllllll}
\hline No & Korelasi & $\begin{array}{c}\text { Koefisien } \\
\text { Korelasi }\end{array}$ & $\begin{array}{c}\text { Tanda } \\
\text { Bintang }\end{array}$ & $\begin{array}{c}\text { Arah } \\
\text { Korelasi }\end{array}$ & $\begin{array}{c}\text { Probabilitas } \\
\text { / Sig. }(\rho)\end{array}$ & Kesimpulan \\
\hline 1 & $\mathrm{X}_{1}-\mathrm{Y}$ & 0,144 & ada & positif & 0,049 & signifikan \\
2 & $\mathrm{X}_{2}-\mathrm{Y}$ & 0,339 & ada & positif & 0,000 & signifikan \\
5 & $\mathrm{M}-\mathrm{Y}$ & 0,540 & ada & positif & 0,000 & signifikan \\
\hline
\end{tabular}

Dari tabel 2 mengenai hasil analisis korelasi didapatkan kesimpulan terdapat hubungan kompetensi guru dengan kinerja guru, kepemimpinan kepala sekolah dengan kinerja guru, motivasi kerja dengan kinerja guru terdapat korelasi yang signifikan.

\section{Uji F (Uji Model)}

Pengujian Kelayakan Model Persamaan regresi menggunakan SPSS didapatkan $F_{\text {hitung }}$ yakni 28,402, sedangkan Ftabel pada tingkat signifikansi 95\% $(\alpha=0,05)$ dengan jumlah responden sebanyak 187 didapatkan $\mathrm{F}_{\text {tabel }}$ dengan derajat bebas (3:184) yakni 2,65. Hal ini menunjukkan bahwa $\mathrm{F}_{\text {hitung }}>\mathrm{F}_{\text {tabel. }}$. Artinya adalah persamaan regresi ini signifikan pada tingkat signifikansi hingga 5\%. Ini menunjukkan bahwa variabel bebas yang digunakan dalam penelitian ini merupakan penjelas nyata pada variabel terikat. Dan menunjukkan pula bahwa model layak

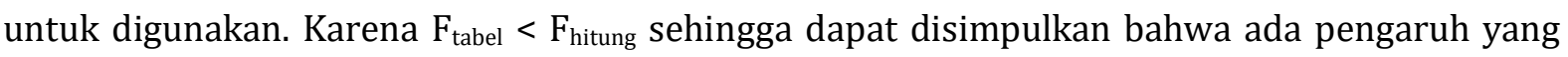
signifikan antara kompetensi guru, kepemimpinan kepala sekolah dan motivasi kerja secara bersama-sama terhadap kinerja guru SMK Negeri di Kabupaten Purbalingga. 


\section{Koefisien Determinasi ( $\left.\mathbf{R}^{2}\right)$}

Dari output pengolahan data menggunakan SPSS didapatkan nilai koefisien determinasi $\left(\mathrm{R}^{2}\right)$ yakni 0,318. Angka tersebut dapat diartikan bahwa kompetensi guru, kepemimpinan kepala sekolah dan motivasi kerja berpengaruh terjadap kinerja guru sebesar 31,80\%. Sedangkan variabel lain yang mempengaruhi kinerja guru yang tidak diteliti dalam persamaan regresi ini sebesar $68,20 \%$.

\section{Uji t}

Hasil analisis uji t dengan pengolahan data menggunakan SPSS adalah sebagai berikut: (1) Nilai

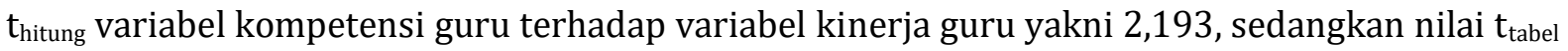
untuk tingkat signifikansi 95\% $(\alpha=0,05)$ didapatkan nilai 1,973. Hal ini menunjukkan bahwa $t_{\text {hitung }}>t_{\text {tabel }}$. Dengan demikian dapat diartikan ada pengaruh yang positif dan signifikan dari kompetensi guru terhadap kinerja guru SMK Negeri di Kabupaten Purbalingga. Dengan kata lain semakin baik kompetensi guru yang dimiliki, maka semakin baik kinerja guru SMK Negeri di Kabupaten Purbalingga. Sehingga hipotesis pertama yang menyatakan kompetensi guru berpengaruh positif dan signifikan terhadap kinerja guru di SMK Negeri se Kabupaten Purbalingga dapat diterima, (2) Nilai thitung variabel kepemimpinan kepala sekolah terhadap variabel kinerja guru yakni 0,983 , sedangkan nilai $t_{\text {tabel }}$ untuk tingkat signifikansi $95 \%(\alpha=0,05)$ didapatkan nilai 1,973. Hal ini menunjukkan bahwa $t_{\text {hitung }}<t_{\text {tabel. }}$. Dengan demikian dapat diartikan tidak ada pengaruh signifikan yang positif dari kepemimpinan kepala sekolah menurut persepsi guru terhadap kinerja guru SMK Negeri di Kabupaten Purbalingga. Dengan kata lain kepemimpinan kepala sekolah menurut persepsi guru secara langsung tidak mempengaruhi kinerja guru SMK Negeri di Kabupaten Purbalingga. Sehingga hipotesis kedua yang menyatakan kepemimpinan kepala sekolah berpengaruh positif dan signifikan terhadap kinerja guru di SMK Negeri se Kabupaten Purbalingga tidak dapat diterima, dan (3) Nilai $t_{\text {hitung }}$ variabel motivasi kerja terhadap variabel kinerja guru yakni 7,230, sedangkan nilai $t_{\text {tabel }}$ untuk tingkat signifikansi 95\% $(\alpha=0,05)$ didapatkan nilai 1,973 . Hal ini menunjukkan bahwa $t_{\text {hitung }}>$ $t_{\text {tabel. }}$. Dengan demikian dapat diartikan ada pengaruh yang positif dan signifikan dari motivasi kerja terhadap kinerja guru SMK Negeri di Kabupaten Purbalingga. Dengan kata lain apabila motivasi kerja seorang guru tinggi maka kinerja guru SMK Negeri di Kabupaten Purbalingga akan menjadi lebih baik. Sehingga hipotesis ketiga yang menyatakan motivasi kerja berpengaruh positif dan signifikan terhadap kinerja guru di SMK Negeri se Kabupaten Purbalingga dapat diterima.

\section{Pembahasan}

Hipotesis pertama (H1) berbunyi "Kompetensi guru berpengaruh positif dan signifikan terhadap kinerja guru SMK Negeri di Kabupaten Purbalingga". Hasil penelitian menunjukkan bahwa kompetensi guru memiliki pengaruh yang positif dan signifikan terhadap kinerja guru. Artinya jika kompetensi guru baik seperti memiliki kepribadian sebagai guru, menguasai landasan pendidikan, menguasai bahan pengajaran, menyusun program pengajaran, melaksanakan proses belajar mengajar, melaksanakan penilaian pendidikan, melaksanakan bimbingan, melaksanakan administrasi, menjalin kerjasama dan interaksi dengan teman sejawat dan masyarakat, serta melaksanakan penelitian sederhana, maka akan menghasilkan kinerja guru SMK Negeri di Kabupaten Purbalingga yang lebih baik. Hasil penelitian ini selaras dengan pernyataan Wibowo (2007: 87) bahwa faktor pengetahuan dan kemampuan mempengaruhi kinerja seorang guru. Sedang menurut Suparlan (2006: 81) kompetensi guru 
adalah pengetahuan, sikap, keterampilan dan nilai-nilai yang ditunjukkan guru dalam melaksanakan kinerja yang diberikan kepadanya. Hasil penelitian ini juga mendukung hasil penelitian terdahulu yang dilakukan oleh Setyono (2011) menunjukkan bahwa terdapat pengaruh positif kompetensi guru terhadap kinerja guru.

Hipotesis kedua (H2) berbunyi "Kepemimpinan Kepala Sekolah berpengaruh positif dan signifikan terhadap kinerja guru SMK Negeri di Kabupaten Purbalingga”. Hasil penelitian menunjukkan bahwa kepemimpinan kepala sekolah tidak berpengaruh signifikan yang positif terhadap kinerja guru SMK Negeri di Kabupaten Purbalingga. Hal ini dikarenakan kepala sekolah memiliki keterbatasan dalam memimpin sebuah SMK sehingga membutuhkan staff yang dapat membantunya dengan membuat struktur organisasi dengan kerangka kerja yang menunjukkan pembagian tugas, pengelompokkan dan garis koordinasi. Seperti yang diungkapkan oleh Robbins dan Coulter (2007) yang menyatakan struktur organisasi adalah kerangka kerja formal organisasi yang dengan kerangka kerja tersebut tugas-tugas pekerjaan dibagi-bagi, dikelompokkan, dan dikoordinasikan. Adapun bentuk struktur organisasi di sekolah umumnya yakni bentuk organisasi lini dan staff, dimana keputusan dan kebijaksanaan tetap sepenuhnya ada pada kepala sekolah, namun kewenangan terbagi-bagi pada masingmasing lini. Untuk membantu tugas dari kepala sekolah di SMK terdapat empat wakil kepala sekolah yakni bidang kurikulum, bidang kesiswaan, bidang sarana dan prasarana, serta bidang hubungan masyarakat dan industri, yang dibantu oleh beberapa staff. Jadi peran kepemimpinan kepala sekolah secara tidak langsung tergantikan oleh peran wakil kepala sekolah dan staffnya. Hasil penelitian untuk hipotesa kedua tidak mendukung penelitian terdahulu yakni hasil penelitian Pratiwi (2013) yang menyatakan terdapat pengaruh positif dari kepemimpinan kepala sekolah menurut persepsi guru terhadap kinerja guru.

Hipotesis ketiga (H3) berbunyi "Motivasi kerja berpengaruh positif dan signifikan terhadap kinerja guru SMK Negeri di Kabupaten Purbalingga". Hasil penelitian menunjukkan bahwa motivasi kerja memiliki pengaruh yang positif dan signifikan terhadap kinerja guru SMK Negeri di Kabupaten Purbalingga. Artinya jika motivasi kerja guru semakin tinggi seperti tanggung jawab guru dalam melaksanakan tugas, melaksanakan tugas dengan target yang jelas, memiliki tuntutan yang jelas dan menantang, ada umpan balik atas hasil pekerjaan, memiliki perasaan senang dalam bekerja, selalu berusaha untuk mengungguli orang lain, mengutamakan prestasi dari apa yang dikerjakan, selalu berusaha untuk memenuhi kebutuhan hidup dan kebutuhan kerjanya, senang memperoleh pujian dari apa yang dikerjakannya, bekerja dengan harapan ingin memperoleh insentif, serta bekerja dengan harapan memperoleh perhatian dari teman dan atasan, maka akan membuat kinerja guru SMK Negeri di Kabupaten Purbalingga menjadi lebih baik. Hal ini selaras dengan yang dikemukakan oleh Rusyan, dkk (2000: 17) salah satu faktor yang mempengaruhi kinerja guru yakni motivasi kerja guru baik internal maupun eksternal. Alice (2004) menyatakan bahwa motivasi kerja guru adalah hasrat yang mendorong seorang guru untuk melakukan pekerjaannya secara lebih bersemangat sehingga akan memperoleh prestasi dan kinerja yang lebih baik. Hasil penelitian ini juga selaras dengan penelitian sebelumnya yakni penelitian Setiyati (2014) yang menyatakan ada pengaruh yang positif dan signifikan antara motivasi kerja terhadap kinerja guru. 


\section{KESIMPULAN DAN SARAN \\ Kesimpulan}

Hasil penelitian menunjukkan bahwa: (1) Terdapat pengaruh yang positif dan signifikan antara kompetensi guru terhadap kinerja guru SMK Negeri di Kabupaten Purbalingga. Hal tersebut dapat disimpulkan bahwa semakin baik kompetensi guru SMK Negeri di Kabupaten Purbalingga, maka akan semakin baik kinerja gurunya. Sebaliknya apabila kompetensi gurunya kurang baik maka akan membuat kinerja guru menjadi kurang baik pula, (2) Tidak ada pengaruh signifikan yang positif antara kepemimpinan kepala sekolah menurut persepsi guru terhadap kinerja guru SMK Negeri di Kabupaten Purbalingga. Hal ini dapat disimpulkan bahwa kepemimpinan kepala sekolah secara langsung belum dapat membuat kinerja guru SMK Negeri di Kabupaten Purbalingga menjadi lebih baik, dan (3) Terdapat pengaruh yang positif dan signifikan antara motivasi kerja terhadap kinerja guru SMK Negeri di Kabupaten Purbalingga. Hal ini dapat disimpulkan bahwa semakin tinggi motivasi kerja seorang guru akan dapat membuat kinerja guru SMK Negeri di Kabupaten Purbalingga menjadi lebih baik, dan sebaliknya apabila motivasi kerja guru rendah maka kinerja guru akan menjadi kurang baik.

\section{Saran}

Adapun saran peneliti yakni: (1) Upaya peningkatan kompetensi guru perlu terus diupayakan untuk meningkatkan kinerja guru. Hal ini dapat dilakukan dengan cara guru mengikuti kegiatan diklat kompetensi yang bisa diadakan melalui sekolah, MGMP, dunia industri, lembaga pendidikan, dan Pemerintah. Selain itu juga dengan adanya tunjangan fungsional guru yakni tunjangan profesi guru dapat dijadikan stimulus bagi guru untuk meningkatkan kompetensinya, dengan cara menganggarkan untuk peningkatan kompetensi seperti mengikuti diklat atau melanjutkan pendidikan ke jenjang yang lebih tinggi, (2) Kepala Sekolah merupakan tenaga fungsional guru yang diberikan tugas tambahan sebagai pejabat struktural yakni untuk memimpin sekolah. Penelitian ini menunjukkan bahwa guru membutuhkan keteladanan dari kepemimpinan kepala sekolah, perhatian dan kontrol terhadap guru-guru yang merupakan anak buahnya, motivasi dari kepala sekolah dalam mengajar, dan komunikasi yang baik dengan semua guru. Apabila semua itu dapat berjalan dengan baik akan dapat meningkatkan kinerja guru, (3) Upaya meningkatan motivasi kerja guru yakni dapat dilakukan dengan memberikan peran atau jabatan kepada guru sesuai dengan kompetensinya, hal ini bertujuan agar pada saat guru bekerja dengan menguasai bidang pekerjaannya akan lebih termotivasi dalam bekerjanya dan memberikan hasil pekerjaan yang baik. Selain itu untuk semakin meningkatkan motivasi kerja guru yakni adanya pengakuan dan penghargaan dari kepala sekolah atas prestasi kerja yang diakibatkan oleh kompetensi guru tersebut, sehingga guru yang awal prestasi kerjanya baik cenderung akan mengikuti guru lain yang prestasi kerjanya biasa saja karena penilaiannya prestasi kerjanya sama, (4) Pada penelitian ini variabel kepemimpinan kepala sekolah berdasarkan persepsi guru, untuk itu pada penelitian selanjutnya variabel kepemimpinan bisa digantikan dengan gaya kepemimpinan seperti transformasional, transaksional, demokrasi, otoriter, karismatik, dan lain-lain, (5) Penelitian ini yang menjadi sampel hanya terbatas guruguru SMK Negeri di Kabupaten Purbalingga, penelitian berikut diharapkan bisa diperluas untuk sampelnya yakni guru SMK Negeri dan SMK Swasta. Karena keberhasilan pendidikan nasional tidak hanya merupakan peran dari guru-guru SMK Negeri tetapi juga guru-guru yang mengajar di SMK Swasta, dan (6) Variabel yang mempengaruhi kinerja guru dalam penelitian ini yakni kompetensi guru, kepemimpinan kepala sekolah dan motivasi kerja. Untuk penelitian berikutnya dimungkinkan menggunakan variabel lain yang mempengaruhi kinerja guru seperti 
Pengaruh Kompetensi Guru, Kepemimpinan Kepala Sekolah Menurut Persepsi Guru dan Motivasi Kerja

Terhadap Kinerja Guru SMK Negeri di Kabupaten Purbalingga

lingkungan kerja, suasana kerja, perilaku kerja, hubungan dengan sesama guru, imbalan jasa, dan sarana pendukung.

\section{DAFTAR PUSTAKA}

Alice T.R. 2004. Hubungan Antara Komunikasi antar Pribadi Guru dan Motivasi Kerja Guru dengan Kinerja Guru SMUK BPK PENABUR Jakarta. Jurnal Pendidikan Penabur-No.03/Th.III

Anderson, S., \& Ball, S. 1978. The Profession and Practice of Program Evaluation. San Francisco : JosseyBass Publisher

Depdiknas. 2004. Pengembangan Perangkat Penilaian Kinerja Guru. Jakarta: Ditjen Dikti, Bagian Proyek P2TK

Dill, Nancy L. 1999. Kompetensi Guru. Diakses pada 13 Agustus 1999, dari http:// ericae.net/ ericda/EDO 090164.html.

Hasibuan, Malayu. 2007. Manajemen Sumber Daya Manusia. Cetakan ke Sembilan, edisi revisi. Jakarta: Bumi Aksara

Kunandar. 2007. Guru Profesional Implementasi KTSP dan Persiapan Menghadapi Sertifikasi Guru. Jakarta: Raja Grafindo Persada

Mulyasa, E. 2005. Menjadi Guru Profesional Menciptakan Pembelajaran Kreatif dan Menyenangkan. Bandung: Remaja Rosdakarya

2007. Standar Kompetensi dan Sertifikasi Guru. Bandung: Remaja Rosdakarya

Murni, Wahid. 2010. Evaluasi Pembelajaran Kompetensi Dan Praktik. Bandung: Remaja Rosda Karya

Newstrom, John W. 2011. Organizational Behavior: Human Behavior at Work. New York America: McGraw-Hill Education

Pratiwi, Suryani Dewi. 2013. Pengaruh Motivasi Kerja, Kepuasan Kerja, Kepemimpinan Kepala Sekolah Menurut Persepsi Guru, dan Iklim Sekolah Terhadap Kinerja Guru Ekonomi SMP Negeri di Kabupaten Wonogiri. Jurnal Pendidikan Insan Mandiri. Universitas Sebelas Maret Surakarta, Vol. 1 No. 1

Purwanto, Ngalim. 1990. Administrasi dan Supervisi Pendidikan. Bandung: Remaja Rosdakarya

Poerwadarminta, W.J.S. 1990. Kamus Besar Bahasa Indonesia. Jakarta: Balai Pustaka

Rahman dkk. 2006. Peran Strategis Kepala Sekolah dalam Meningkatkan Mutu Pendidikan. Jatinangor: Alqa print

Rizal, Anis Syamsul. 2015. Kinerja Guru, Motivasi Kerja dan Kedisiplinan. Diakses pada 12 Juni 2015, dari http://zalssyam.blogspot.com/2015/06/kinerja-guru-motivasi-kerja-dan.html.

Rusyan, Tabrani dkk. 2000. Upaya Meningkatkan Budaya Kinerja Guru. Cianjur: CV. Dinamika Karya Cipta

Robbins, S dan Coulter, M. 2007. Manajemen Edisi Kedelapan. Jakarta : PT Indeks

Sahertian, Piet A. 1994. Profil Pendidik Profesional. Yogyakarta: Andi Offset

Salam, Dharma Setyawan. 2002. Manajemen Pemerintahan Daerah. Jakarta: Djambatan

Sastrohadiwiryo, B. Siswanto. 2002. Manajemen Tenaga Kerja Indonesia Pendekatan Administrasi dan Operasional. Jakarta : Bumi Aksara

Setiyati, Sri. 2014. Pengaruh Kepemimpinan Kepala Sekolah, Motivasi Kerja, dan Budaya Sekolah Terhadap Kinerja Guru. Jurnal Pendidikan Teknologi dan Kejuruan, Gunung Kidul, Vol. 22 No. 2 
Setyono, Hendro. 2011. Pengaruh Kompetensi Guru, Insentif dan Lingkungan Kerja Fisik Terhadap Kinerja Guru SMA Negeri 1 Patimuan Kabupaten Cilacap. Jurnal Nasional SAINTEKS. Universitas Muhammadiyah Purwokerto, Vol. 7 No. 2, pp. 90-101

Siregar, Edi. 2011. Pengaruh Motivasi Kerja, Kinerja Individual dan Sistem Kompensasi Finansial terhadap Kepuasan Kerja. Jurnal Pendidikan Penabur. No.16/Tahun ke-10/Juni 2011

Slameto. 2010. Belajar dan Faktor-Faktor yang Mempengaruhinya. Jakarta: Rineka Cipta

Sugiyono. 2015. Metode Penelitian Kuantitatif Kualitatif dan R\&D. Bandung: Alfabeta

Supardi. 2014. Kinerja Guru. Jakarta: PT Raja Grafindo Persada

Suparlan. 2006. Guru Sebagai Profesi. Yogyakarta: Hikayat Publishing

Syadam, Gouzali. 1996. Manajemen Sumber Daya Manusia (Human Resources Management) Suatu Pendekatan Mikro (Dalam Tanya Jawab). Jakarta: Djambatan

Timpe, A Dale. 1993. Kinerja. Jakarta: PT. Gramedia

Uno, Hamzah B. 2008. Teori Motivasi dan Pengukurannya. Jakarta: Bumi Aksara

Wagner, John A dan John R. Hollenbeck. 1995. Management of Organizational Behavior, Second Edition, New Jersey: Prentice-Hall, Inc

Wahjosumidjo. 2011. Kepemimpinan Kepala Sekolah: Tinjauan Teoretik dan Permasalahannya. Jakarta: PT. Raja Grafindo Persada

Wahyudi. 2009. Kepemimpinan Kepala Sekolah dalam Organisasi Pembelajaran. Bandung: Alfabeta

Wibowo. 2007. Manajemen Kinerja. Jakarta: PT. Raja Grafindo Parsada

Winardi. 2002. Motivasi dan Pemotivasian dalam Manajemen. Jakarta: PT Raja Grafindo Persada 